\title{
Occurrence and diet analysis of sea turtles in Korean shore
}

Jihee Kim , II-Hun Kim², Min-Seop Kim³ ${ }^{3}$ Hae Rim Lee ${ }^{4}$, Young Jun Kim, Sangkyu Park and Dongwoo Yang ${ }^{2^{*}}$ (D)

\begin{abstract}
Background: Sea turtles, which are globally endangered species, have been stranded and found as bycatch on the Korean shore recently. More studies on sea turtles in Korea are necessary to aid their conservation. To investigate the spatio-temporal occurrence patterns of sea turtles on the Korean shore, we recorded sampling locations and dates, identified species and sexes and measured sizes (maximum curved carapace length; CCL) of collected sea turtles from the year 2014 to 2020. For an analysis of diets through stomach contents, we identified the morphology of the remaining food and extracted DNA, followed by amplification, cloning, and sequencing.

Results: A total of 62 stranded or bycaught sea turtle samples were collected from the Korean shores during the study period. There were 36 loggerhead turtles, which were the dominant species, followed by 19 green turtles, three hawksbill turtles, two olive ridley turtles, and two leatherback turtles. The highest numbers were collected in the year 2017 and during summer among the seasons. In terms of locations, most sea turtles were collected from the East Sea, especially from Pohang. Comparing the sizes of collected sea turtles according to species, the average $C C L$ of loggerhead turtles was $79.8 \mathrm{~cm}$, of green turtles was $73.5 \mathrm{~cm}$, and of the relatively large leatherback turtle species was $126.2 \mathrm{~cm}$. In most species, the proportion of females was higher than that of males and juveniles, and was more than $70 \%$ across all the species. Food remains were morphologically identified from 19 stomachs, mainly at class level. Seaweeds were abundant in stomachs of green turtles, and Bivalvia was the most detected food item in loggerhead turtles. Based on DNA analysis, food items from a total of 26 stomachs were identified to the species or genus level. The gulfweed, Sargassum thunbergii, and the kelp species, Saccharina japonica, were frequently detected from the stomachs of green turtles and the jellyfish, Cyanea nozakii, the swimming crab, Portunus trituberculatus, and kelps had high frequencies of occurrences in loggerhead turtles.
\end{abstract}

Conclusions: Our findings support those of previous studies suggesting that sea turtles are steadily appearing in the Korean sea. In addition, we verified that fish and seaweed, which inhabit the Korean sea, are frequently detected in the stomach of sea turtles. Accordingly, there is a possibility that sea turtles use the Korean sea as feeding grounds and habitats. These results can serve as basic data for the conservation of globally endangered sea turtles.

Keywords: Sea turtle, Stranding, Stomach contents, Diet analysis, Korean shore

\footnotetext{
* Correspondence: dwyang@mabik.re.kr

${ }^{2}$ Department of Ecology and Conservation, National Marine Biodiversity

Institute of Korea, Seocheon 33662, Republic of Korea

Full list of author information is available at the end of the article
}

(c) The Author(s). 2021 Open Access This article is licensed under a Creative Commons Attribution 4.0 International License, which permits use, sharing, adaptation, distribution and reproduction in any medium or format, as long as you give appropriate credit to the original author(s) and the source, provide a link to the Creative Commons licence, and indicate if changes were made. The images or other third party material in this article are included in the article's Creative Commons licence, unless indicated otherwise in a credit line to the material. If material is not included in the article's Creative Commons licence and your intended use is not permitted by statutory regulation or exceeds the permitted use, you will need to obtain permission directly from the copyright holder. To view a copy of this licence, visit http://creativecommons.org/licenses/by/4.0/. 


\section{Background}

Sea turtles are keystone species in coastal ecosystems (Stringell et al. 2016). Globally, seven sea turtle species belonging to six genera of two families exist, which are distributed from the Arctic Ocean $\left(70{ }^{\circ} \mathrm{N}\right)$ to the Tasman Sea (45 ㅇ) (Márquez 1990; Klemens 2000; Lee et al. 2014). All sea turtle species are listed in the Convention on International Trade in Endangered Species of Wild Fauna and Flora (CITES) because of their declining population caused by overhunting, habitat destruction, pollution, and climate change (Moon et al. 2009). In addition, the International Union for Conservation of Nature (IUCN) classified six sea turtle species as critically endangered (CR), endangered (EN), or vulnerable (VU). However, flatback turtles (Natator depressus) were not classified because of insufficient data (IUCN 2021). Among these classified turtles, green turtles (Chelonia mydas) and leatherback turtles (Dermochelys coriacea) were first reported in the 1930s (Hironobu 1936a; 1936b), and loggerhead turtles (Caretta caretta) were reported in the 1960s (Won 1971) on the Korean coast. Additionally, hawksbill turtles (Eretmochelys imbricata) have been recorded (Jung et al. 2012a). Recently, olive ridley turtles (Lepidochelys olivacea) were reported for the first time from the coastal waters of South Korea (Kim et al. 2019). Following international efforts to protect sea turtles, these five species were designated as "Marine Organisms under Protection" by the Conservation and Management of Marine Ecosystems Act in Korea (MOF (Ministry of Oceans and Fisheries) 2021).

Studies on the ecology of sea turtles in Korea are limited because of their low occurrence frequency, which in turn is because Korean shores are not the main habitats and nesting areas for these species as compared with other warm temperate and tropical countries (Wallace et al. 2010; Haywood et al. 2019). Studies on the status of stranding and bycatch of sea turtles, including their distribution, satellite tracking, and nesting places, in Korea began in the late 2000s (Moon et al. 2011; Jung et al. 2012b). Lee et al. (2014) comprehensively described the morphology of loggerhead turtles from the Yellow Sea of Korea. Koo et al. (2014) reported hybridization between loggerhead and green turtles from Jeju Island, South Korea. Further, Jang et al. (2018) investigated the spatiotemporal movements of green turtles in the Jeju Island Sea, Korea. Recently, the number of deadstranded sea turtles on the Korean shore has been increasing, and there is growing concern about the protection of this species in the nation. However, comprehensive research on sea turtles is still lacking and more studies are needed on the status of sea turtles in Korea to conserve them (Kim et al. 2017).

Understanding animal feeding ecology provides information about their habitat requirements, thereby promoting scientific conservation (Prior et al. 2015). Monitoring sea turtles through direct observation and indirect monitoring methods, such as observing feeding signs and using video or radio telemetry are not often undertaken, because more than $99 \%$ of their lives are spent at sea, thereby making them largely inaccessible (Tomas et al. 2001). Thus, their feeding ecology has been mainly studied globally by sampling the stomach and esophagus of dead individuals from strandings, fishery bycatch, or by direct collection (Mortimer 1981; Shaver 1991; Plotkin et al. 1993; Tomas et al. 2001; Stringell et al. 2016), or by lavages of the stomach and esophagus of live individuals (Forbes and Limpus 1993; CarriónCortez et al. 2010; Prior et al. 2015). Accordingly, green turtles have been reported to feed primarily on algae, especially Ulva spp. and/or seagrass such as Thalassia testudinum, and their diet varies depending on their habitats (Carrión-Cortez et al. 2010). Further, loggerhead turtles primarily feed on fish and benthic invertebrates, such as crustaceans and mollusks (Plotkin et al. 1993; Tomas et al. 2001). To date, few studies on sea turtle diets have been conducted in Korea. Moon et al. (2009) reported the occurrence of sea turtles in Korean waters and dissected their digestive tracts. They observed seaweed, such as Ulva spp., Sargassum spp., and Gelidium spp. in the digestive tracts of three green turtles and animal food sources such as mackerel, hairtail, squid, and $\mathrm{crab}$, in the stomach of a loggerhead turtle. In most studies, researchers directly identified food remains in the digestive tract with the naked eye and/or indirectly through a microscope using morphological characteristics. Although these conventional methods are easily accessible, there is a possibility of misidentification, which poses further limitations (Reynolds and Aebischer 1991; Pires et al. 2011). Therefore, complementary methods, such as molecular analysis, can be applied to dietary studies of marine predators (Deagle et al. 2005; Dunn et al. 2010). Diet analyses using DNA can provide substantive and accurate information regarding food sources, which cannot be obtained through direct observation and radio telemetry (Kim et al. 2021). Furthermore, this approach is efficient in terms of labor and time requirements compared with the morphological and microhistological analyses of digestive contents (Joo et al. 2014). Additionally, it has higher resolution than conventional approaches by the identification of prey to the genus or species level (Zhao et al. 2020).

In this regard, this study aimed to provide information about the occurrence patterns and feeding ecology of sea turtles in South Korea to enable their conservation. This information can help identify important food resources and foraging areas necessary for establishing regulations and policies regarding the management of endangered sea turtle populations (Bjorndal 1999; Behera et al. 
2015). Specifically, we investigated (1) the spatiotemporal patterns of sea turtles found stranded or as bycatch on the Korean shore and (2) the diets of sea turtles through stomach analysis.

\section{Materials and methods \\ Sample collection}

Dead sea turtles occurring on the South Korean shores due to stranding or bycatch events from August 2014 to September 2020 were collected and transferred to the National Marine Biodiversity Institute of Korea (MABIK) from other research institutes and government agencies, which primarily collected the sea turtle after receiving observation reports by a finder. A total of 62 sea turtles in the form of carcasses, skeletons, and stuffed specimens were transferred with relevant information, such as the location and date of stranding/bycatch, turtle species, and sex. According to the condition of the samples, maximum curved carapace length (CCL), sexual maturity, and wet weight were measured and recorded except for skeleton and highly decayed carcasses of samples. Subsequently, fresh frozen carcasses were moved to the National Institute of Ecology (NIE) for necropsy and dissected to separate food items in stomach contents according to a veterinarian's guidelines for sea turtles (Flint et al. 2009). Determination of sexual maturity was based on CCL size at sexual maturity: $95 \mathrm{~cm}$ in $C$. mydas, $66.5 \mathrm{~cm}$ in C. caretta, and $125 \mathrm{~cm}$ in D. coriacea (Avens and Snover 2013). However, sexual maturity of some individuals and species was determined by veterinary examination through necropsy.

\section{Morphological and molecular analysis of stomach contents}

The stomach contents of the sea turtles, except for skeleton and highly decayed carcasses of samples, were sieved with a $1 \mathrm{~mm}$ mesh, and items, such as shell, carapace, and seaweed, which were larger than the mesh size and could be sorted with the naked eye, were collected and washed with distilled water. Items that appeared as food were separated into plant and animal food items. Subsequently, we identified the items morphologically at the class level with a taxonomic reference (Hong et al. 2006) and recorded non-food objects (stone and anthropogenic materials, among others) in green $(n=3)$, loggerhead $(n=15)$, and olive ridley turtles $(n=1$, Table 2$)$.

Tissues under good conditions were selected for further molecular analysis in green $(n=9)$, loggerhead $(n=$ 16), and leatherback turtles $(n=1$, Table 3$)$. Genomic DNA was extracted from the tissue samples using the QIAamp ${ }^{\circ}$ Blood \& Tissue Kit (Qiagen, Germany) following the manufacturer's instructions with a flexible duration for lysis from $3 \mathrm{~h}$ to overnight depending on the sample conditions.

All polymerase chain reaction (PCR) amplifications were conducted using $20 \mu \mathrm{l}$ sample solution, containing $1 \mu \mathrm{l}$ of extracted DNA, $0.25 \mu \mathrm{M}$ of each primer, and $1 \mathrm{U}$ of FastMix/Frenche ${ }^{\text {mi }}$ PCR (i-StarTaq) premix (iNtRON, Korea). The PSf/Ur primer pair and the Uf/PSr pair (Stiller and McClanahan 2005) were used to amplify the plastid $16 \mathrm{~S}$ gene to identify herbivorous food items, such as terrestrial plants and macroalgae (Table 1). The PCR mixture was denatured at $95^{\circ} \mathrm{C}$ for $4 \mathrm{~min}$, followed by 35 cycles of $30 \mathrm{~s}$ at $94^{\circ} \mathrm{C}, 30 \mathrm{~s}$ at $60^{\circ} \mathrm{C}$, and $90 \mathrm{~s}$ at $72^{\circ} \mathrm{C}$, and a final extension at $72{ }^{\circ} \mathrm{C}$ for $7 \mathrm{~min}$. To identify the animal-based food items, the mitochondrial-encoded cytochrome oxidase subunit I (COI) region was amplified using LCO1490 and HCO2198 primers (Vrijenhoek 1994), and the 12S rRNA gene was amplified using MiFish-U/E primers (Miya et al. 2015), especially for fish. PCR was performed in a thermal cycler (Applied Biosystems, USA) using the following conditions: initial denaturation for $3 \mathrm{~min}$ at $94{ }^{\circ} \mathrm{C}$, followed by 45 cycles at $94{ }^{\circ} \mathrm{C}$ for $45 \mathrm{~s}, 50^{\circ} \mathrm{C}$ for $1 \mathrm{~min}$, and $72{ }^{\circ} \mathrm{C}$ for $1 \mathrm{~min}$, and a final extension for $5 \mathrm{~min}$ at $72{ }^{\circ} \mathrm{C}$ to amplify the COI region. PCR conditions for the $12 \mathrm{~S}$ region were set as follows: initial denaturation at $95^{\circ} \mathrm{C}$ for $5 \mathrm{~min}$, followed by 40 cycles of denaturation at $95^{\circ} \mathrm{C}$ for $15 \mathrm{~s}$, annealing at

Table 1 Information on primer set used in this study

\begin{tabular}{|c|c|c|c|}
\hline Target & Primer & Sequence $\left(5^{\prime}-3^{\prime}\right)$ & Reference \\
\hline \multirow[t]{4}{*}{ Algae (16S) } & PSf & GGGATsTAGATACCCCWGTAGTCCT & Stiller and McClanahan 2005 \\
\hline & Ur & TACGGYTACCTTGTTACGACTT & \\
\hline & Uf & GAGAGTTTGATCCTGGTCAG & \\
\hline & PSr & AGGACTACWGGGGTATCTAATCCC & \\
\hline \multirow[t]{4}{*}{ Fish (12S) } & MiFish-E-F & GTTGGTAAATCTCGTGCCAGC & Miya et al. 2015 \\
\hline & MiFish-E-R & CATAGTGGGGTATCTAATCCTAGTITG & \\
\hline & MiFish-U-F & GTCGGTAAAACTCGTGCCAGC & \\
\hline & MiFish-U-R & CATAGTGGGGTATCTAATCCCAGTTTG & \\
\hline \multirow[t]{2}{*}{ Animal (COI) } & LCO1490 & GGTCAACAAATCATAAAGATATTGG & Vrijenhoek 1994 \\
\hline & HCO2198 & TAAACTTCAGGGTGACCAAAAAATCA & \\
\hline
\end{tabular}


$58{ }^{\circ} \mathrm{C}$ for $30 \mathrm{~s}$, and elongation at $72{ }^{\circ} \mathrm{C}$ for $30 \mathrm{~s}$, followed by a final extension at $72^{\circ} \mathrm{C}$ for $7 \mathrm{~min}$.

The PCR products were purified using an AccuPrep ${ }^{\circ}$ PCR Purification Kit (Bioneer, Korea). Sequencing was performed using a commercial sequencing service company (Genotech, Korea). For ambiguous sequencing results, purified PCR products were inserted into the pGEM $^{\circ}$ - T Easy Vector (Promega, USA) and transformed into competent DH5 $\alpha$ cells. The cells were spread on Luria-Bertani agar + ampicillin medium with $2 \% \mathrm{X}$-gal $(\mathrm{w} / \mathrm{v})$ solution to facilitate antibiotic selection and bluewhite screening. After cloning, the cell colonies were selected and amplified using the M13F and M13R primers. Each resultant sequence was identified by BLASTN analysis using the GenBank database.

\section{Data analysis}

We conducted Chi square tests to determine seasonal differences in the number of stranded and bycaught turtles. To understand the relationship between water temperature and sea turtle occurrence, we analyzed water temperature records in the stranding/bycatch areas during the sampling period using data from the Korea Hydrographic and Oceanographic Agency (KHOA). Dietary analysis results using morphological and molecular methods were presented as frequency of occurrence (\% FO), representing the percentage of individuals in which a food item was found among analyzed sea turtles by each method. In addition, information on the sampling sites of seaweeds and marine algae in Korea (Lee and Kang 2001; Kim et al. 2013), the distribution map acquired from the Marine Bio-Resource Information System (MBRIS, www.mbris.kr), and Ocean Biodiversity Information System (OBIS, www.obis.org) were used to investigate the local distribution of seaweeds among the observed food items.

\section{Results}

Spatio-temporal occurrence patterns of sea turtles

A total of 62 sea turtles were collected during the entire study period. Loggerhead turtle, $C$. caretta, was the most dominant species (36 individuals, 58.1\%), followed by green turtle, C. mydas (19 individuals, 30.6\%), hawksbill turtle, E. imbricata (three individuals, $4.8 \%$ ), and olive ridley, L. olivacea, and leatherback turtle, D. coriacea (two individuals each, 3.2\%) (Fig. 1). In terms of years, most sea turtles were collected in 2017, with 21 individuals (33.9\%), followed by 14 individuals (22.6\%) in 2018 and nine individuals (14.5\%) in 2019. Since 2016, three or more species were collected, and olive ridley turtles were collected only in 2017 (two individuals).

Regarding collection months, sea turtles were most frequently collected in October, followed by June. In addition, green turtles and loggerhead turtles (relatively

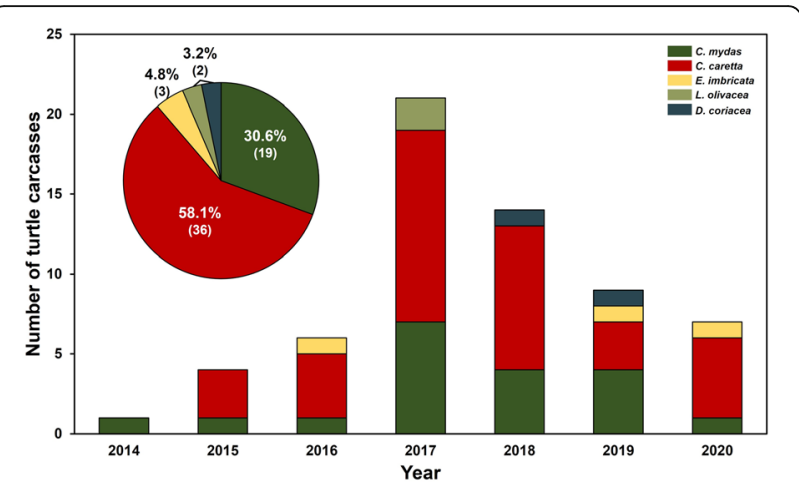

Fig. 1 Bar graph showing the number of occurrences of sea turtle carcasses in coastal regions, Korea, collected by MABIK during the study period (2014-2020). Pie chart showing proportions of species of all sea turtles with the number of carcasses in parentheses

high number of individuals) were collected throughout the study period, except in January, February, and April (Fig. 2). To investigate the difference in the numbers of the pairs of species according to the sampling months, we conducted a chi-square test; however, no statistically

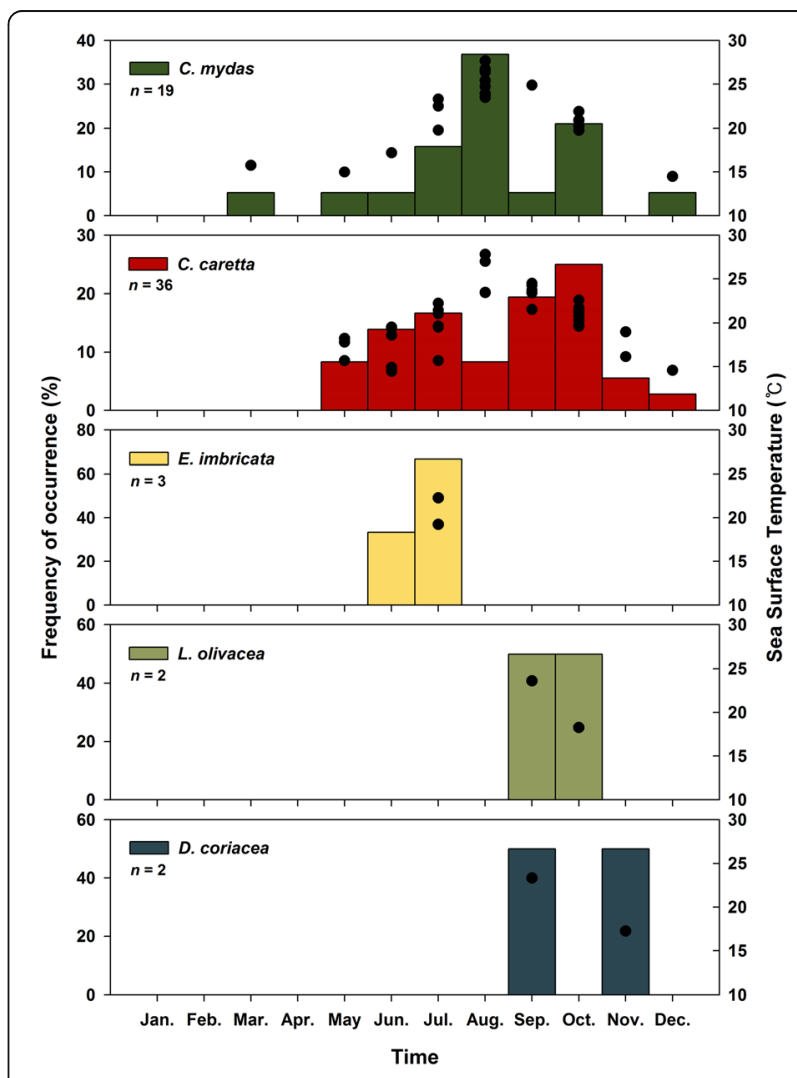

Fig. 2 Bar graph showing the monthly distribution of occurred sea turtles during the study period (2014-2020). Closed circles indicating daily mean of sea surface temperature (SST) for 15 days before collection, measuring near the stranding site based on data from the Korea Hydrographic and Oceanographic Agency (KHOA) 
significant difference was observed $\left(\chi^{2}=11.54, p=\right.$ 0.173). Further, three hawksbill turtles were collected in June and July, two olive ridley turtles in September and October, and two leatherback turtles in September and November.

Of the 61 individuals (data missing for one individual), the highest number of sea turtles $(n=20,32.8 \%)$ was collected from the East Sea, specifically near Pohang, followed by Jeju Island ( $n=9,14.8 \%$ ) (Fig. 3). Green turtles and loggerhead turtles were collected from all Korean waters, including the West Sea. Hawksbill turtles were collected only from the South Sea, olive ridley turtles were collected only from the East Sea, while leatherback turtles were collected only from Samcheok in the East Sea.

We measured the size of 56 individuals among the samples, considering their condition. The average CCL of green turtles was $73.5 \mathrm{~cm}(n=18$, juveniles: $43.3-$ $74.0 \mathrm{~cm}$; adults: $74.8-106.6 \mathrm{~cm}$ ) and that of loggerhead turtles was $79.8 \mathrm{~cm}(n=33$, juveniles: $42.0 \mathrm{~cm}$; adults: $58.8-93.5 \mathrm{~cm})($ Fig. 4), while that of a hawksbill turtle individual was $88.8 \mathrm{~cm}$. Moreover, the $\mathrm{CCL}$ of the two olive ridley turtles were 65.1 and $66.2 \mathrm{~cm}$, and those of the relatively large leatherback turtles were 114.0 and $138.4 \mathrm{~cm}(n=2)$. The size thresholds for CCL between adults and juveniles have been reported to be 95, 66.5, and $125 \mathrm{~cm}$ (green, loggerhead, and leatherback turtles, respectively; Avens and Snover 2013). However, the size at sexual maturity in species was determined by

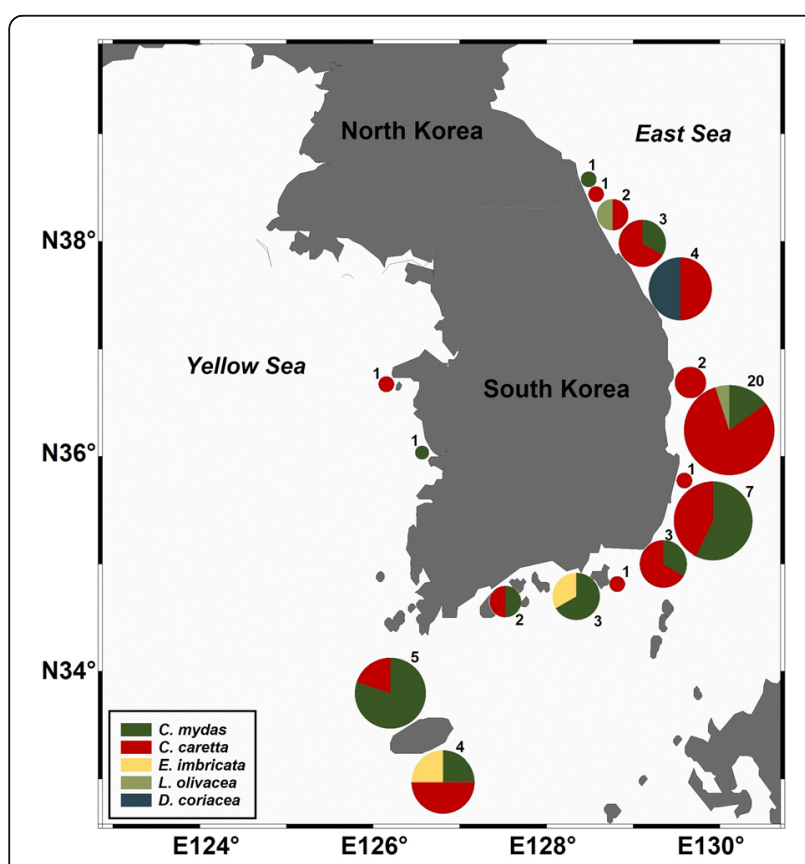

Fig. 3 Map showing occurrence locations of sea turtles in this study. Pie chart showing proportions of species of collected sea turtles with total number of individuals at each location

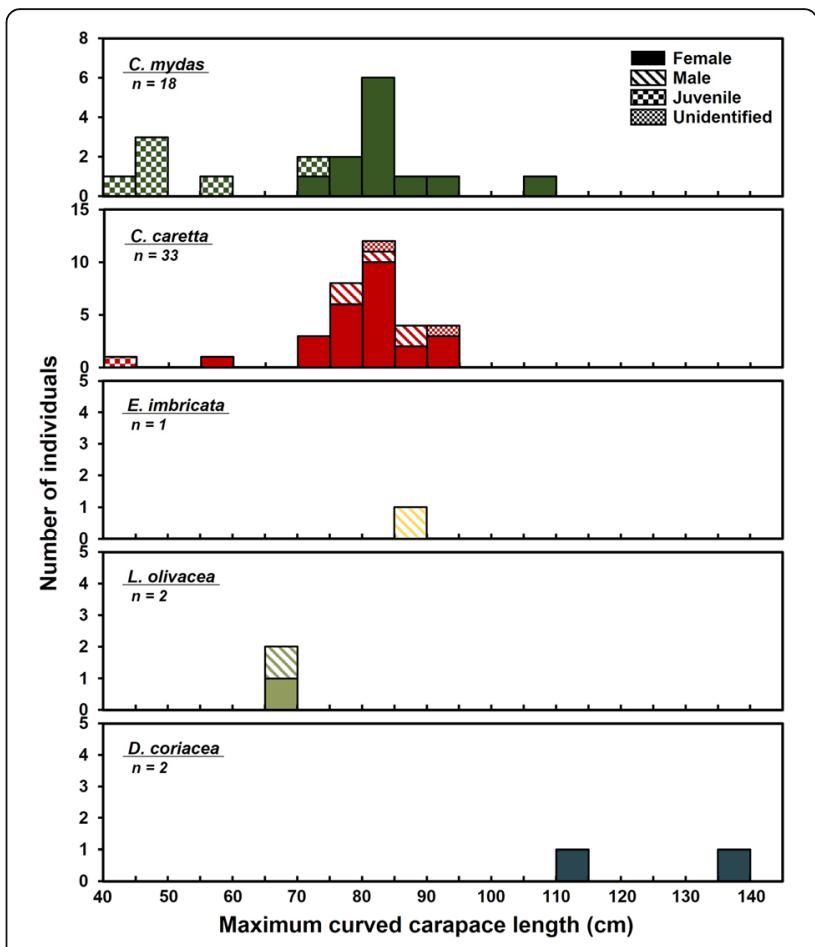

Fig. 4 Stacked bar graph showing distribution of maximum curved carapace length $(\mathrm{CCL})$ of occurred turtles by sexual group and stage

measuring methods (straight or curved carapace length), techniques (mark-recapture, length frequency, skeletochronology, among other methods), and populations. In our study, the sizes were approximately $75 \mathrm{~cm}$ in green turtles, $59 \mathrm{~cm}$ in loggerhead turtles, and $114 \mathrm{~cm}$ in leatherback turtles through the necropsy method. Consequently, the proportion of females was more than $70 \%$ in sea turtles. Among the 18 green turtle individuals, 12 were females and six were juveniles. A total of 33 loggerhead turtle individuals comprised 25 females, 5 males, and 1 juvenile. One male hawksbill turtle was recorded, and two female leatherback turtles were identified. A male and a female were identified in the two olive ridley turtle individuals (Fig. 4).

\section{Dietary composition of the sea turtles found stranded or as bycatch on the Korean shores}

Morphological analysis of stomach contents revealed the presence of a few animal-based food items, but several plant-based food items were found in all three green turtle individuals (Table 2). Based on morphological identification, various seaweed species such as Grateloupia spp., Chondrus spp., and Sargassum spp. were also observed (Fig. 5A). Bivalves such as Veneridae were most frequently detected in the stomachs of 15 loggerhead turtles, followed by Polychaeta and Osteichthyes representing animal-based food items (Fig. 5B), and plantbased food items were also detected. However, only 
Table 2 Stomach contents of green (Chelonia mydas), loggerhead (Caretta caretta), and olive ridley (Lepidochelys olivacea) sea turtles identified by morphological analysis at class level, and the percentage frequency of occurrence (\% FO), with the number of stomachs the item occurred in $n$. Plant materials included all items of plant origin and macroalgae, and synthetic flotsam included plastics, styrofoam, and nylon cord/string

\begin{tabular}{|c|c|c|c|c|c|c|}
\hline \multirow[t]{2}{*}{ Stomach content } & \multicolumn{2}{|l|}{ Green turtles } & \multicolumn{2}{|c|}{ Loggerhead turtles } & \multicolumn{2}{|c|}{ Olive ridley turtles } \\
\hline & $\%$ FO $(n=3)$ & $n$ & $\%$ FO $(n=15)$ & $n$ & $\%$ FO $(n=1)$ & $n$ \\
\hline Synthetic flotsam & 67 & 2 & 87 & 13 & 100 & 1 \\
\hline \multicolumn{7}{|l|}{ Phylum Cnidaria } \\
\hline Cl. Anthozoa & & & 7 & 1 & & \\
\hline \multicolumn{7}{|c|}{ Phylum Arthropoda, sub ph. Crustacea } \\
\hline Cl. Malacostraca & & & 40 & 6 & 100 & 1 \\
\hline Cl. Cirripedia & 33 & 1 & 13 & 2 & 100 & 1 \\
\hline \multicolumn{7}{|l|}{ Phylum Mollusca } \\
\hline Cl. Gastropoda & & & 20 & 3 & & \\
\hline Cl. Bivalvia & & & 73 & 11 & 100 & 1 \\
\hline Cl. Cephalopoda & & & 20 & 3 & & \\
\hline \multicolumn{7}{|l|}{ Phylum Chordata } \\
\hline Cl. Osteichthyes & 33 & 1 & 47 & 7 & & \\
\hline Cl. Ascidiacea & & & 7 & 1 & & \\
\hline \multicolumn{7}{|l|}{ Phylum Brachiopoda } \\
\hline Cl. Articulata & & & 7 & 1 & & \\
\hline \multicolumn{7}{|l|}{ Phylum Annelida } \\
\hline Cl. Polychaeta & & & 53 & 8 & & \\
\hline Plant & 100 & 3 & 53 & 8 & & \\
\hline Stone & & & 7 & 1 & & \\
\hline
\end{tabular}
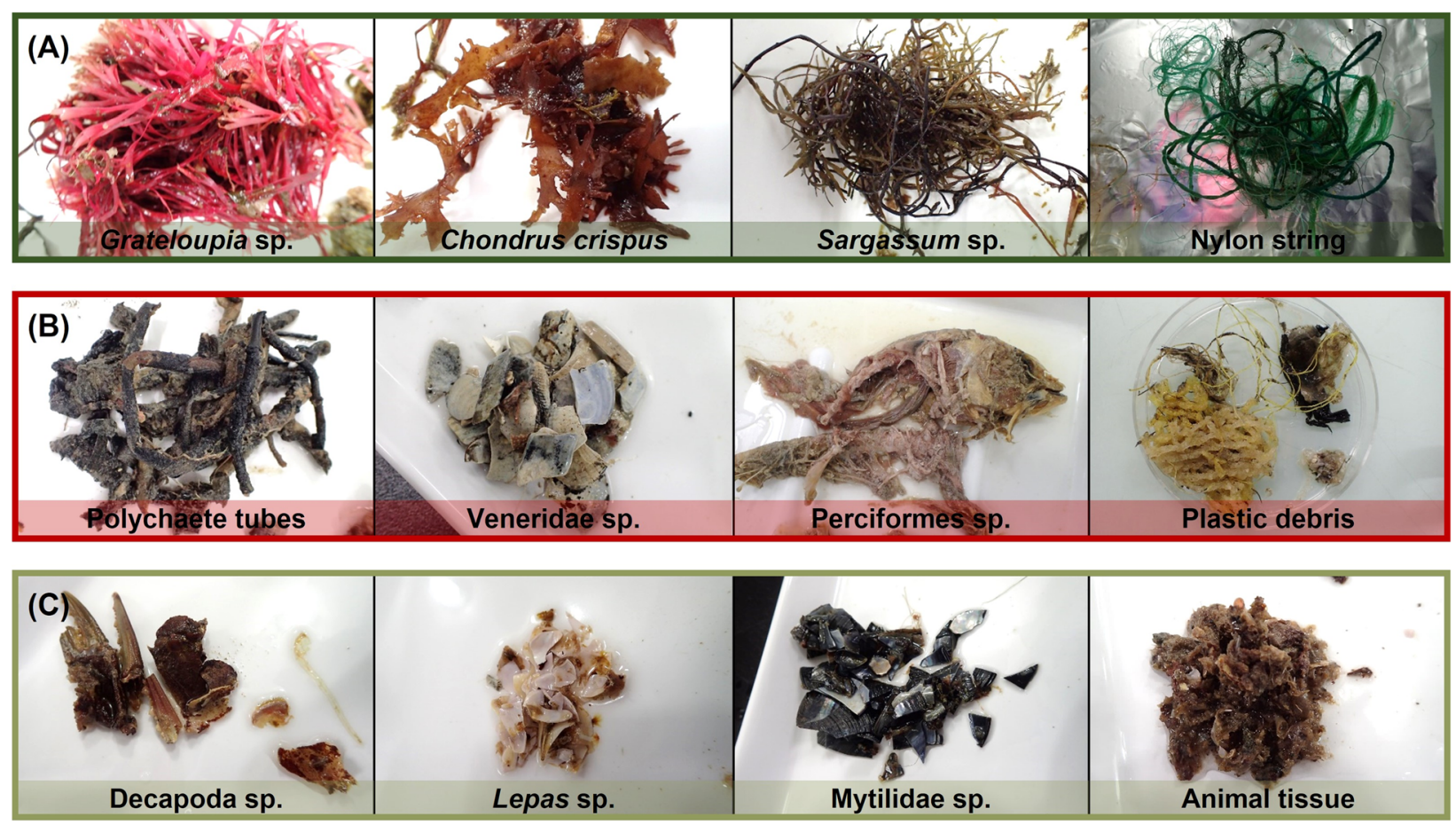

Fig. 5 Images of stomach contents of green turtles, Chelonia mydas (A), loggerhead turtles, Caretta caretta (B), and olive ridley turtles, Lepidochelys olivacea $(\mathbf{C})$, in this study 
animal-based food items, such as animals belonging to Cirripedia (Lepas spp.) and Bivalvia (Mytilidae spp.), were observed in an olive ridley turtle (Fig. 5C). Synthetic flotsams, including plastics, styrofoam, and nylon cords/strings, comprised most of the other collected objects from the turtle stomachs (Table 2).

To supplement the resolution of morphological analysis to identify food items, DNA analysis was performed. Our results showed that 44 taxa of 33 genera and 34 species were observed in the stomach samples of the sampled turtles (Table 3). The gulfweed, Sargassum thunbergii (55.6\% FO, $n=9$ ), and the kelp species, Saccharina japonica (44.4\% FO, $n=9$ ), were frequently detected in the stomachs of green turtles. Furthermore, the jellyfish, Cyanea nozakii, and the swimming crab, Portunus trituberculatus (each $25 \%$ FO, $n=16$ ), were found most frequently in loggerhead turtles. In addition, S. japonica ( $25 \% \mathrm{FO}, n=16)$ was the most frequently detected plant-based food item. In the stomach of the leatherback turtle, $P$. trituberculatus, and the species of Gastropoda, Nassarius sinarus, were detected; however, these results may not reflect the food preference of leatherback turtles because of the insufficient number of analyzed samples.

Among the 41 sequences detected from the stomach contents of nine green turtles, which included four juveniles and five females, 90.2\% comprised plant-based items and 9.8\% comprised animal-based items (Table 4). The analyzed sequences from the stomachs of 15 loggerhead turtles, which included one juvenile, nine females, and five males, indicated that plant-based and animalbased items comprised $30.6 \%$ and $69.4 \%$, respectively.

\section{Discussion}

\section{Spatio-temporal occurrence patterns of sea turtles}

According to the results of our study (Fig. 1) and those of previous studies (Moon et al. 2011; Jung et al. 2012a; Kim et al. 2017), sea turtles have been continuously observed due to their declining populations caused by stranding and bycatch in the coastal regions of Korea in the last two decades. Kim et al. (2017) assessed the number of dead or alive sea turtles in the Korean coastal regions from the year 1949 to July 2016 by referring to diverse data sources (e.g., newspaper articles, published reports, and research data). They reported that occurrence of approximately 1-9 sea turtles per year was due to stranding and bycatch in the past 20 years. Our study recorded 21 carcasses in 2017. MABIK initiated the study of sea turtles, including necropsy, and received a higher number of sea turtle carcasses from research groups and government agencies, such as the Cetacean Research Institute (CRI), the Hanwha Aqua Planet Yeosu, and the Korea Coast Guard, Korea, in 2017 than in other years. Consequently, the largest number of samples was collected in 2017, after which a decreasing trend was observed. In this study, we considered the number of sea turtle samples collected only by MABIK; thus, more sea turtles could be stranded annually than the number recorded in Korea during the study period.

The trends in the occurrence of sea turtles from 1949 to July 2016 in the Korean coastal waters analyzed by Kim et al. (2017) showed that green turtles (58.8\%) were more prevalent than loggerhead turtles (31.5\%), especially on Jeju Island. Based on satellite tracking data, green turtles were mainly observed to remain on Jeju Island (Moon et al. 2011; Jung et al. 2012a; Jang et al. 2018). In this study, we collected more loggerhead turtles $(58.1 \%)$ than green turtles $(30.6 \%)$, and most individuals of the former species originated from Pohang (Figs. 1 and 3). The collection of sea turtle carcasses from Jeju Island has been limited because of transportation difficulties. Despite the limitation of sampling, our results showed that the distribution of stranded or bycaught turtles in Korean shores differed according to the species. Green turtles had a higher proportion in the South Sea than other species, while loggerhead turtle numbers increased in the East Sea (Fig. 2). These results are consistent with those reported by Kim et al. (2017). This distribution pattern might be related to the habitat and habits related to migration and foraging. Rasmussen et al. (2011) suggested that the distribution of sea turtles, Cheloniidae and Dermochelyidae, was primarily along tropical coasts and across oceans, including all Korean coasts. Loggerhead and green sea turtles migrate to a comparable range of oceans, such as the Atlantic, Mediterranean, Indian, and Pacific oceans (Wallace et al. 2010). However, the nesting sites and foraging habits are dissimilar between the two species. Nesting sites of green sea turtles are reported to be distributed from $30^{\circ}$ $\mathrm{N}$ to $23^{\circ} \mathrm{S}$ (e.g., coasts of Australia, Philippines, and Vietnam) (Wallace et al. 2010; Figgener et al. 2019). In addition, they show a dietary shift through the development stage, consuming Gastropoda, Scyphozoa, and Malacostraca as juveniles and expanding to mainly plant food sources such as seagrass and mangrove materials as adults (Jones and Seminoff 2013). However, loggerhead sea turtles mainly nest in the northwestern Atlantic, Mediterranean, and northern Pacific regions, including Japan, and principally have animal diets such as Cephalopoda, Actinopterygii, and Bivalvia with seagrass and algae (Wallace et al. 2010; Jones and Seminoff 2013). Some records have described that they arrived on Korean breeding grounds located on Jeju Island and the coasts of the East Sea (Kim et al. 2017). Loggerhead sea turtles, which had a high proportion of adults in this study, could migrate to the East Sea for breeding with foraging activity, thus increasing the possibility of occurrence in the eastern areas. Fishes, such as Scomber spp. 
Table 3 Stomach contents of green (Chelonia mydas), loggerhead (Caretta caretta), and leatherback (Dermochelys coriacea) sea turtles identified by DNA analysis at species or genus level, and the percentage frequency of occurrence (\% FO), with the number of stomachs the item occurred in $n$ (* represents the species detected from stomach contents of leatherback turtle, $n=1$ )

\section{Stomach content \\ hylum Cnidaria \\ Cl. Scyphozoa}

Cyanea nozakii

C. mydas

Green turtle

$\%$ FO $(n=9)$

Portunus trituberculatus

Portunus sanguinolentus

Pagurus spp.

Phylum Mollusca

Cl. Gastropoda

Cl. Bivalvia

Cl. Cephalopoda

Phylum Chordata

Cl. Actinopterygii

Cl. Ascidiacea

\section{Phylum Rhodophyta}

Cl. Florideophyceae

Nassarius sinarus
Rapana venosa
Turbo cornutus
Mytilus spp.
Mytilus galloprovincialis
Octopus vulgaris
Todarodes pacificus

Scomber spp.

Scomber japonicus

Scomberomorus niphonius

Decapterus maruadsi

Psenopsis spp.

Sphyraena pinguis

Hippocampus spp.

Ascidia aspersa

Grateloupia spp.
Grateloupia turuturu
Grateloupia angusta
Grateloupia filicina
Grateloupia lanceola
Grateloupia taiwanensis
Prionitis abbreviata
Polyopes constrictus
Ceramium sungminbooi
Melanothamnus harveyi
Gelidium elegans
Pterocladiella capillacea
Chondrus crispus
Gracilaria textorii
Scinaia undulata

C. caretta

Loggerhead turtle $\%$ FO $(n=16)$
22.2

$n$

25.0

25.0

6.3

6.3

11.1

6.3

6.3

6.3

6.3

12.5

11.1

6.3

6.3

6.3

6.3
4 2

\section{.}

-


Table 3 Stomach contents of green (Chelonia mydas), loggerhead (Caretta caretta), and leatherback (Dermochelys coriacea) sea turtles identified by DNA analysis at species or genus level, and the percentage frequency of occurrence (\% FO), with the number of stomachs the item occurred in $n$ (* represents the species detected from stomach contents of leatherback turtle, $n=1)($ Continued)

\begin{tabular}{|c|c|c|c|c|c|}
\hline \multirow[t]{3}{*}{ Stomach content } & & \multirow{2}{*}{\multicolumn{2}{|c|}{$\frac{\text { C. mydas }}{\text { Green turtle }}$}} & \multirow{2}{*}{\multicolumn{2}{|c|}{$\frac{\text { C. caretta }}{\text { Loggerhead turtle }}$}} \\
\hline & & & & & \\
\hline & & $\%$ FO $(n=9)$ & $n$ & $\%$ FO $(n=16)$ & $n$ \\
\hline \multicolumn{6}{|l|}{ Phylum Ochrophyta } \\
\hline \multirow[t]{4}{*}{ Cl. Phaeophyceae } & Sargassum spp. & 22.2 & 2 & 12.5 & 2 \\
\hline & Sargassum thunbergii & 55.6 & 5 & 6.3 & 1 \\
\hline & Sargassum horneri & 22.2 & 2 & 12.5 & 2 \\
\hline & Saccharina japonica & 33.3 & 3 & 25.0 & 4 \\
\hline \multirow[t]{2}{*}{ Cl. Ulvophyceae } & Codium fragile & 11.1 & 1 & & \\
\hline & Ulva spp. & 11.1 & 1 & & \\
\hline \multicolumn{6}{|c|}{ Phylum Magnoliophyta } \\
\hline \multirow[t]{2}{*}{ Cl. Liliopsida } & Zostera marina & 22.2 & 2 & & \\
\hline & Alisma plantago-aquatica & 11.1 & 1 & & \\
\hline \multirow[t]{2}{*}{ Cl. Magnoliopsida } & & 11.1 & 1 & & \\
\hline & Family. Tamaricaceae & & & 6.3 & 1 \\
\hline \multicolumn{6}{|l|}{ Phylum Pinophyta } \\
\hline Cl. Pinopsida & Pinus spp. & 11.1 & 1 & 6.3 & 1 \\
\hline
\end{tabular}

and Decapterus maruadsi which are distributed in the Korean sea (Lee et al. 2018; Zhao et al. 2021), were detected in the stomachs of loggerhead turtles (Table 3). Moreover, the distribution of sessile seaweed (Lee and Kang 2001; Kim et al. 2013), such as S. japonica, S. thunbergii, and Sargassum horneri, which occur frequently in the stomach contents, overlapped with the collected locations of sea turtles (Fig. 6). This suggests that sea turtles can feed on animals and seaweeds on the Korean shore.

Leatherback sea turtles have a wider range of movement than other species and nesting distribution from $38{ }^{\circ} \mathrm{N}$ to $34^{\circ} \mathrm{S}$ (Wallace et al. 2010; Figgener et al. 2019). Based on satellite telemetry data, leatherback turtles

Table 4 Relative frequencies of plants and animal food sources sequences detected from stomachs of green turtles (Chelonia mydas) and loggerhead turtles (Caretta caretta) at life stage or sex

\begin{tabular}{lllll}
\hline & $\begin{array}{l}\text { No. of } \\
\text { analyzed } \\
\text { individuals }\end{array}$ & $\begin{array}{l}\text { No. of } \\
\text { sequences }\end{array}$ & \multicolumn{2}{c}{ Relative frequency } \\
\cline { 4 - 5 } & $\mathbf{9}$ & $\mathbf{4 1}$ & $\mathbf{9 0 . 2}$ & $\mathbf{9 . 8}$ \\
\hline Green turtle & 4 & 8 & 75.0 & 25.0 \\
Juvenile & 5 & 33 & 93.9 & 6.1 \\
Female & $\mathbf{1 5}$ & $\mathbf{3 6}$ & $\mathbf{3 0 . 6}$ & $\mathbf{6 9 . 4}$ \\
Loggerhead turtle & $\mathbf{2 0 . 6}$ & 50.0 & 50.0 \\
Juvenile & 1 & 2 & 34.6 & 65.4 \\
Female & 9 & 26 & 12.5 & 87.5 \\
Male & 5 & 8 & &
\end{tabular}

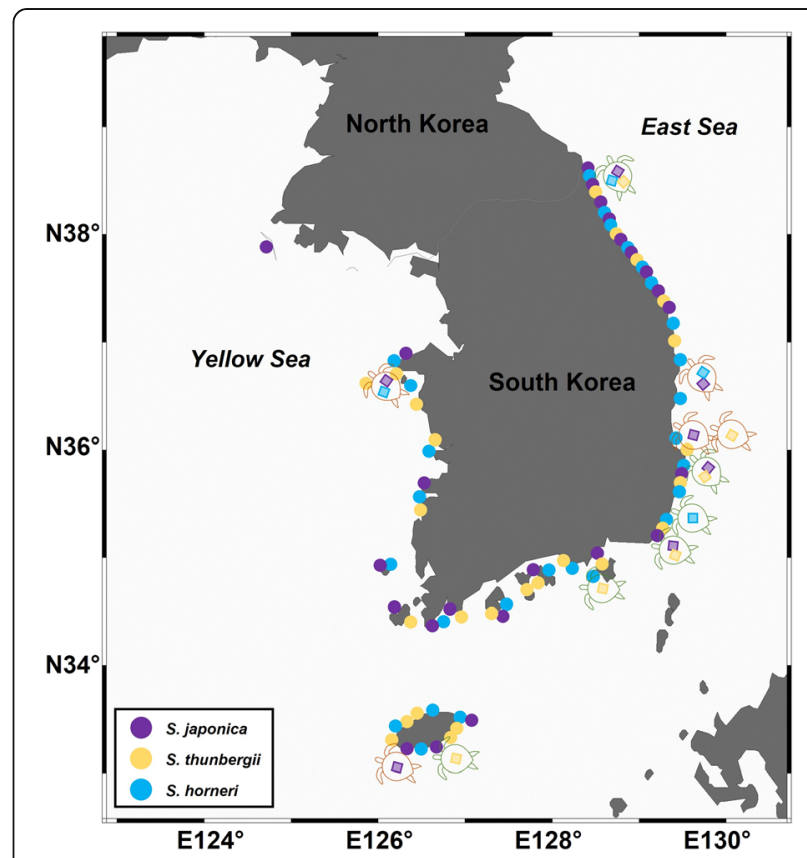

Fig. 6 Map showing distribution of dominant prey items of seaweeds (Saccharina japonica, Sargassum thunbergii, and Sargassum horneri) based on results of DNA analysis, and sampling sites of green and loggerhead sea turtles feeding with the prey items 
moved along the East Sea of Korea, a transit zone, in November and December (Benson et al. 2011). Our results showed a relevant distribution pattern; leatherback turtles were found only on the eastern coast in September and November (Figs. 2 and 3). Loggerhead, green, and leatherback turtles have been reported to appear on the eastern and southern coasts of Korea (Kim et al. 2017). On the western coast, however, accidently captured live loggerhead turtles were found in a waste fishing net (Lee et al. 2014). In this study, a loggerhead turtle and a green turtle were stranded on the western coast. Chan et al. (2007) reported that leatherback, loggerhead, green, and hawksbill turtles were observed in the Yellow Sea, China. Based on the reference, both leatherback and hawksbill turtles are likely to be observed on the western coast of Korea in the future.

In our study, olive ridley turtles were found only in the eastern coastal region, while hawksbill turtles were found in southern coastal regions, including Jeju Island. These two species have a narrow range of in-water distributions and nesting distribution, concentrated in tropical regions, compared with other species (Wallace et al. 2010; Figgener et al. 2019), and the turtles were observed in lower latitudinal regions than those of other species observed in the Yellow Sea, China (Chan et al. 2007). Olive ridley turtles, which were recently found in Korean waters, were reported to be stranded in the East China Sea (Chan et al. 2007) and in Japanese waters, including the western coast of the East Sea (Fukuoka et al. 2019). However, there is insufficient information regarding the distribution of this species along the Korean shore (Kim et al. 2019).

The distribution and behavior of sea turtles are influenced by the water temperature. Cold water reduces their activity, resulting in a cold-stunned state due to physiological effects (Williard et al. 2013). In loggerhead turtles, locomotor abilities are weakened below $15^{\circ} \mathrm{C}$, and turtles may be cold-stunned below $10^{\circ} \mathrm{C}$ (Mansfield and Putman 2013). In this study, the occurrence of sea turtles was concentrated during the summer and autumn. We calculated the average water temperature near the sampling sites for 15 days before turtle sampling using data from KHOA. However, some values were missing from the KHOA dataset. We assumed that the estimated time of death is within 15 days considering drifting time and carcass decomposition of the sea turtles referred to a study by Santos et al. (2018) despite different environmental conditions. The average and minimum temperatures were found to be $20.5^{\circ} \mathrm{C}$ ( $\mathrm{SD}=$ $3.4^{\circ} \mathrm{C}$ ) and $13.5^{\circ} \mathrm{C}$, respectively. Only five individuals $(8.2 \%)$ were observed at temperature below $15^{\circ} \mathrm{C}$. Our results indicated that most sea turtles in the Korean shores possibly had not reduced their activity because of the cold environments in the collection months.
Regarding the proportion of occurrence, most sea turtles, especially loggerhead turtles, were found in the eastern coasts of Korea during the study period. The eastern coasts maintain a relatively high water temperature even in winter because of the influence of the East Korean Warm Current, a branch of the Tsushima Warm Current (TWC) (Choi et al. 2012). Moreover, the TWC is known to affect marine ecosystems, dissolved inorganic nutrients (Won and Lee 2015), and the composition of fish assemblages (Lee et al. 2008) on the Korean coast. Furthermore, the distribution of sea turtles is influenced not only by physical phenomena, such as ocean currents and water temperature but also by the movement and distribution of food sources (Jung et al. 2012a). In this study, the occurrence of omnivorous loggerhead turtles in the East Sea was believed to be due to the flow of ocean currents and food sources. In our satellite tracking study, loggerhead turtles were observed to move along the coast of the East Sea and toward Japan (data not shown, manuscript in preparation), supporting the possibility of turtle appearance on the Korean coast by swimming, and not by drifting of the carcass.

\section{Dietary composition of the sea turtles stranded or as bycatch on the Korean shores}

In this study, we elucidated the diet of sea turtles through morphological and molecular analyses of stomach contents. Morphological analysis of food items is limited by the difficulty in accurate identification because of damage during capture, ingestion, and digestion (Jarman et al. 2004). However, DNA-based diet analysis methods generally have higher resolutions than morphological methods (Zhao et al. 2020), and are less laborious and use prior knowledge (Valentini et al. 2009). Based on the genetic analysis of the prey collected from the stomach samples of the sampled sea turtles, we identified the prey to the species or genus level, thereby resulting in 31 families, 33 genera, and 34 species, whereas morphological analysis identified the diet at higher taxonomic levels, such as class level.

Moreover, various plant food items were observed in the stomachs of three green turtle individuals using the morphological method (Table 2, Fig. 5A). Cirripedia, barnacle, and osteichthyes could also be directly identified with the naked eye. We detected 41 sequences of 18 genera and 21 species in nine green turtle stomachs by molecular analysis (Table 3). Green turtles are generally omnivorous, with a strong carnivorous tendency during young and juvenile life stages in open ocean pelagic habitats (Bjorndal 1985; Jones and Seminoff 2013; VélezRubio et al. 2016; Burgett et al. 2018). Dietary reports from small pelagic green turtles are few, but some records show that their diet consists of seagrass and small species of Ctenophora and Mollusca (Hughes 1974; Frick 
1976; Fuentes et al. 2006). However, they shift to a herbivorous diet and occupy a unique feeding niche when they enter benthic foraging areas (Lutz et al. 2002; Howell et al. 2016). Many studies have been conducted on the food sources of green turtles in various oceans and countries (Esteban et al. 2020). The findings of these studies suggested that feeding primarily on seagrasses and algae was common, although they also consumed animals, particularly jellyfish, salps, and sponges (Mortimer 1981; Fukuoka et al. 2019; Piovano et al. 2020). The main food of green turtles stranded in Hong Kong was red algae such as Grateloupia filicina, Gelidium pusillum, and Pterocladiella tenuis (Russell and Balazs 2009; Russell and Balazs 2015; Ng et al. 2016), which are also distributed along the coast of Korea (Guiry and Guiry 2016; NIBR 2020). In Australia, red algae were dominant, followed by brown and green algae in green turtle stomachs (Garnett et al. 1985; André et al. 2005). In addition, gelatinous animal tissues, such as those of Physalia and mollusk eggs, were observed in the stomach lavage (Forbes and Limpus 1993). Algae comprised the diet of sea turtles in Japan (Kurata et al. 1978), and 56 species of algae were included in the diet of green turtles in the Hawaiian Archipelago (Balazs 1980). Furthermore, digestive tracts of green turtles stranded on the Korean shore consisted of seaweed such as Ulva spp., Sargassum spp., and Gelidium spp. (Moon et al. 2009). In our study, various plant materials were detected in the stomachs of most green turtles. Brown algae were predominant, particularly Sargassum spp. and S. japonica. Similar to previous studies, the proportion of red algae was also high, among which 14 species were identified, including five Grateloupia spp. Furthermore, C. nozakii and Mollusca, such as Nassarius sinarus and Octopus vulgaris, were also identified, although their frequency was low.

Although the number of juvenile green turtles studied was insufficient, the frequency of plant-based food items was higher than that of animal-based food items (Table 4). Similarly, the proportion of plant sequences was higher in the female samples. Although bias in the amplification and digestibility differences may occur, a sufficient number of samples and well-planned analysis can facilitate the understanding of dietary differences in juveniles and adults using molecular methods.

In the loggerhead turtles, stomach contents comprised various taxa, with the frequency of Mollusca being the highest based on morphological analysis (Table 2). Further, DNA analysis revealed 37 sequences of 18 genera and 16 species in 16 loggerhead turtle stomachs (Table $3)$. Loggerhead turtles are considered generalists and versatile predators of slow-moving or sessile prey (Dodd Jr 1988; Plotkin et al. 1993; Tomas et al. 2001), thus, contributing to diverse diets across geographical localities (Burke et al. 1993; Plotkin et al. 1993; Thomson et al. 2012). Therefore, to date, various prey taxa have been identified for this turtle species in many regions. The diets range widely from marine animals and plants to terrestrial insects, such as ants, planthoppers, and beetles (Richardson and McGillivary 1991). Crustaceans, especially crabs, and gelatinous animals (medusae and ctenophores) are important prey for this species (Burke et al. 1993; Tomas et al. 2001). In addition, pelagic coelenterates, salps, gastropods, barnacles, anemones, and sargassum have been identified as dietary components of loggerhead turtles in many studies (Brongersma 1972; Van Nierop and den Hartog 1984). In Korea, the stomach contents of loggerhead turtles mainly consisted of animal-based food materials such as mackerel, hairtail, and squid (Moon et al. 2009), with crabs and jellyfish as the major food sources (Table 3). Brown algae, such as Saccharina and Sargassum, were dominant plant-based food items in the loggerhead turtle stomachs, similar to green turtles, along with a high frequency of animal content. Arthropoda, including crabs, and Chordata, including fishes, were diverse, and Mollusca and Cnidaria with soft tissue were also detected in the stomachs. There is a dietary shift in loggerhead turtles among seasons (Bjorndal 2017). They feed mainly on sea pens in spring and crabs in summer and autumn when the abundance of crabs increases (Plotkin et al. 1993). However, turtle stomach samples for dietary analysis in this study were collected only in summer and autumn from June to October; therefore, we could not determine the dietary shifts. A difference in the number of detected sequences between female and male turtles was observed, but the frequency of animal sequences was higher than that of plant sequences, regardless of the sex of the loggerhead turtles (Table 4).

Our results showed that diverse food items were consumed by turtle species, similar to the findings of previous studies. For example, loggerhead turtles were generally omnivores (Fukuoka et al. 2016), and green turtles were classified as herbivores on maturity (Stringell et al. 2016) based on morphological and molecular methods. The diets of olive ridley and leatherback turtles were analyzed from only one sample each using morphological and molecular methods, respectively. Arthropoda and Mollusca were commonly found in the stomachs of the two species; however, the results may not reflect their respective food preferences due to an insufficient number of analyzed samples.

Sea turtles mainly contained Sargassum spp., S. japon$i c a$, and Zostera marina in plant items, and P. trituberculatus and C. nozakii in animal items in Korean shores based on our results (Table 3), although we could not verify that the stomach remains were preferences or merely remained in the stomachs among consumed items. Among the main diets, some species are 
consumed as seafood by humans in Korea. Such marine organisms have been directly and indirectly threatened and their populations have reduced due to marine pollution, coastal development, and overexploitation (Park and Lee 2007; Oh 2011). For the conservation of sea turtles, which are part of marine ecosystems, it is critical to sustain food sources and habitats by the designation of marine protected areas, restoration of habitats, and management of fisheries resources.

In addition, we suggest that water pollution by plastic debris should be managed for sea turtles. Synthetic flotsam, including plastics, styrofoam, and nylon cords/ strings, were found in 16 of the 19 stomach samples (Table 2). It was not confirmed whether these pollutants caused stranding and death of the turtles; however, these results show that water pollution by plastic debris is a growing environmental issue worldwide. It affects at least 267 species, including $86 \%$ of all sea turtle species (Laist 1997). However, the problem is prone to be underestimated because it is difficult to find a majority of the victims across the vast ocean (Wolfe 1987). The ingestion of plastic debris by marine organisms occurs in every region of the world and in all the studied seven turtle species (Schuyler et al. 2014), with the probability of mortality and plastic concentration in the digestive tract being positively correlated (Wilcox et al. 2018). In particular, polythene bags floating on the ocean look similar to the prey of turtles (Mattlin and Cawthorn 1986; Gramentz 1988; Bugoni et al. 2001; Derraik 2002). Intake of plastic is the main cause of non-natural death of these animals (NMFS 1998), inducing intoxication, obstruction of the esophagus, or perforation of the bowel (Mascarenhas et al. 2004). Young sea turtles are particularly vulnerable to plastic pollution (Carr 1987).

For over 50 years, long-term monitoring and protection of nesting sites in some locations have resulted in stabilization or an increase in sea turtle populations (Kelle et al. 2009; Delcroix et al. 2014; Laloë et al. 2020; Mortimer et al. 2020; Godley et al. 2020). These projects have emphasized the importance of protecting nesting and foraging habitats and promoting the participation of local communities, citizens, volunteers, and tourists (Godley et al. 2020). In addition to these international efforts, many studies on the ecology of sea turtles, including our research on feeding ecology, could promote awareness regarding the necessity of sea turtle conservation.

\section{Conclusions}

In summary, we investigated the occurrence patterns and feeding ecology of sea turtles on the coasts of Korea. Our findings showed that sea turtles are steadily appearing in the Korean sea, and the dietary analysis of the stomach contents indicated that they may be utilizing the sea as a feeding ground. These results can serve as baseline data for the conservation of globally endangered sea turtles. In future studies, stable isotope analysis of tissues can provide more information regarding the food preferences and trophic positions of sea turtles in the Korean sea. In addition, research on the migration route of sea turtles through satellite telemetry is required to understand the spatial ecology and habitat use of sea turtles in the Korean and neighboring waters.

\section{Abbreviations}

CCL: Maximum curved carapace length; CITES: Convention on International Trade in Endangered Species of Wild Fauna and Flora; IUCN: International Union for Conservation of Nature; KHOA: Korea Hydrographic and Oceanographic Agency; MABIK: Marine Biodiversity Institute of Korea; MBRIS: Marine Bio-Resource Information System; NIE: National Institute of Ecology; OBIS: Ocean Biodiversity Information System; SD: Standard deviation; SST: Sea surface temperature

\section{Acknowledgements}

We would like to thank Dr. Hye Seon Kim, Dr. Chang Ho Yi, In-Young Cho, Seong Joon Bae, and Ji Min Kim in MABIK, and Sugil Lee, So Jin Jeon, Young Hae Jang, Ji Yeon Park, and Se Rim Chin in NIE for assisting the necropsy and this study, and anonymous reviewers for their valuable and constructive suggestions.

\section{Authors' contributions}

JK performed the analysis, and wrote the manuscript. IHK and MSK designed and organized a project including this study. HRL and YJK organized and conducted the necropsy. SP reviewed and edited the manuscript. DY planned this study, performed the analysis, and wrote/reviewed the manuscript. All authors read and approved the final manuscript.

\section{Funding}

This study was supported by a grant from the National Marine Biodiversity Institute of Korea (2021 M00300).

\section{Availability of data and materials}

The datasets generated during and/or analyzed during the current study are available from the corresponding author on reasonable request.

\section{Declarations}

Ethics approval and consent to participate Not applicable.

\section{Consent for publication}

Not applicable.

\section{Competing interests}

The authors declare that they have no competing interests.

\section{Author details \\ ${ }^{1}$ Department of Biological Science, Ajou University, Suwon 16499, Republic of Korea. ${ }^{2}$ Department of Ecology and Conservation, National Marine Biodiversity Institute of Korea, Seocheon 33662, Republic of Korea. ${ }^{3}$ Department of Taxonomy and Systematics, National Marine Biodiversity Institute of Korea, Seocheon 33662, Republic of Korea. ${ }^{4}$ Division of Zoological Research and Management, National Institute of Ecology, Seocheon 33657, Republic of Korea.}

Received: 4 October 2021 Accepted: 4 November 2021

Published online: 21 November 2021

\section{References}

André J, Gyuris E, Lawler IR. Comparison of the diets of sympatric dugongs and green turtles on the Orman Reefs, Torres Strait, Australia. Wildl Res. 2005; 32(1):53-62. https://doi.org/10.1071/WR04015. 
Avens L, Snover ML. Age and age estimation in sea turtles. In: The Biology of Sea Turtles, Volume III. Boca Raton: CRC press; 2013. p.97-134.

Balazs $\mathrm{GH}$. Field methods for sampling the dietary components of green turtles Chelonia mydas. Herp Review. 1980;11(1):5-6.

Behera S, Tripathy B, Sivakumar K, Choudhury BC. Stomach Contents of Olive Ridley Turtles (Lepidochelys Olivacea) Occurring in Gahirmatha, Odisha Coast of India. Springer. 2015;68(1):91-5. https://doi.org/10.1007/s12595-014-0100-0.

Benson SR, Eguchi T, Foley DG, Forney KA, Bailey H, Hitipeuw C, et al. Large-scale movements and high-use areas of western Pacific leatherback turtles, Dermochelys coriacea. Ecosphere. 2011;2(7):1-27. https://doi.org/10.1890/ ES11-00053.1.

Bjorndal KA. Nutritional ecology of sea turtles. Copeia. 1985;3(3):736-51. https:// doi.org/10.2307/1444767.

Bjorndal KA. Priorities in foraging habitats. In: Eckert KL, Bjorndal KA, AbrellGrobois FA, Donnelly M, editors. Research and management technique for conservation of sea turtles, vol. 4. Blanchard: IUCN Marine Turtle Specialist Group;1999. p.12-5.

Bjorndal KA. Foraging ecology and nutrition of sea turtles. In: The Biology of Sea Turtles, Volume I. Boca Raton: CRC press; 2017. p.199-231.

Brongersma LD. European atlantic turtles. Zool Verh. 1972;121(1):1-318.

Bugoni L, Krause L, Petry MV. Marine debris and human impacts on sea turtles in southern Brazil. Mar Pollut Bull. 2001;42(12):1330-4. https://doi.org/10.1016/ S0025-326X(01)00147-3.

Burgett CM, Burkholder DA, Coates KA, Fourqurean VL, Kenworthy WJ, Manuel SA, et al. Ontogenetic diet shifts of green sea turtles (Chelonia mydas) in a mid-ocean developmental habitat. Mar Biol. 2018;165(2):1-12. https://doi. org/10.1007/s00227-018-3290-6.

Burke VJ, Standora EA, Morreale SJ. Diet of juvenile Kemp's ridley and loggerhead sea turtles from Long Island. New York. Copeia. 1993;4(4):1176-80. https:// doi.org/10.2307/1447107.

Carr A. Impact of nondegradable marine debris on the ecology and survival outlook of sea turtles. Mar Pollut Bull. 1987;18(6):352-6. https://doi.org/10.101 6/S0025-326X(87)80025-5.

Carrión-Cortez JA, Zárate P, Seminoff JA. Feeding ecology of the green sea turtle (Chelonia mydas) in the Galapagos Islands. J Mar Biol Assoc United Kingdom. 2010;90(5):1005-13. https://doi.org/10.1017/S0025315410000226.

Chan SKF, Cheng IJ, Zhou T, Wang HJ, Gu HX, Song XJ. A comprehensive overview of the population and conservation status of sea turtles in China. Chelonian Conserv Biol. 2007;6(2):185-98. https://doi.org/10.2744/1071-8443 (2007)6[185:ACOOTP]2.0.CO;2.

Choi BJ, Byun DS, Lee KH. Satellite-altimeter-derived East Sea surface currents: estimation, description and variability pattern. Sea. 2012;17(4):225-42. https:// doi.org/10.7850/jkso.2012.17.4.225.

Deagle BE, Jarman SN, Pemberton D, Gales NJ. Genetic screening for prey in the gut contents from a giant squid (Architeuthis sp.). J. Hered. 2005;96(4):417-23. https://doi.org/10.1093/jhered/esi036.

Delcroix E, Bédel S, Santelli G, Girondot M. Monitoring design for quantification of marine turtle nesting with limited effort: a test case in the Guadeloupe archipelago. Oryx. 2014;48(1):95-105. https://doi.org/10.1017/S0030605311 000792.

Derraik JGB. The pollution of the marine environment by plastic debris: a review. Mar Pollut Bull. 2002;44(9):842-52. https://doi.org/10.1016/S0025-326X(02 )00220-5.

Dodd CK Jr. Synopsis of the biological data on the loggerhead sea turtle Caretta Caretta (Linnaeus 1758). US Fish Wildl Serv, Biol Rep. 1988;88(14):1-110.

Dunn MR, Szabo A, McVeagh MS, Smith PJ. The diet of deepwater sharks and the benefits of using DNA identification of prey. Deep Sea Res. Part I Oceanogr. Res. Pap. 2010;57(7):923-30.

Esteban N, Mortimer JA, Stokes HJ, Laloë JO, Unsworth RKF, Hays GC. A global review of green turtle diet: sea surface temperature as a potential driver of omnivory levels. Mar Biol. 2020;167(12):1-17. https://doi.org/10.1007/s00227020-03786-8

Figgener C, Bernardo J, Plotkin PT. Beyond trophic morphology: stable isotopes reveal ubiquitous versatility in marine turtle trophic ecology. Biol Rev. 2019; 94(6):1947-73. https://doi.org/10.1111/brv.12543.

Flint M, Patterson-Kane JC, Limpus CJ, Work TM, Blair D, Mills PC. Postmortem diagnostic investigation of disease in free-ranging marine turtle populations: a review of common pathologic findings and protocols. J Vet Diagnostic Investig. 2009;21(6):733-59. https://doi.org/10.1177/104063870902100601.

Forbes GA, Limpus CJ. A non-lethal method for retrieving stomach contents from sea turtles. Wildl Res. 1993;20(3):339-43. https://doi.org/10.1071/WR9930339.
Frick J. Orientation and behaviour of hatchling green turtles (Chelonia mydas) in the sea. Anim Behav. 1976;24(4):849-57. https://doi.org/10.1016/S0003-3472 (76)80015-2.

Fuentes MMPB, Lawler IR, Gyuris E. Dietary preferences of juvenile green turtles (Chelonia mydas) on a tropical reef flat. Wildl Res. 2006;33(8):671-8. https:// doi.org/10.1071/WR05081.

Fukuoka T, Kinoshita C, Sato K. Northernmost bycatch record of an olive ridley turtle (Lepidochelys olivacea) in the Pacific Coast of Japan. Mar Turt Newsl. 2019;159:17-22.

Fukuoka T, Yamane M, Kinoshita C, Narazaki T, Marshall GJ, Abernathy KJ, et al. The feeding habit of sea turtles influences their reaction to artificial marine debris. Sci Rep. 2016;6(1):1-11. https://doi.org/10.1038/srep28015.

Garnett ST, Price IR, Scott FJ. The diet of the green turtle, Chelonia mydas (L.), in Torres Strait. Wildl Res. 1985;12(1):103-12. https://doi.org/10.1071/WR9850103.

Godley BJ, Broderick AC, Colman LP, Formia A, Godfrey MH, Hamann M, et al. Reflections on sea turtle conservation. Oryx. 2020;54(3):287-9. https://doi. org/10.1017/S0030605320000162.

Gramentz D. Involvement of loggerhead turtle with the plastic, metal, and hydrocarbon pollution in the central Mediterranean. Mar Pollut Bull. 1988; 19(1):11-3. https://doi.org/10.1016/0025-326X(88)90746-1.

Guiry MD, Guiry GM. AlgaeBase. National University of Ireland, Galway: Worldwide electronic publication; 2016. http://www.algaebase.org.

Haywood JC, Fuller WJ, Godley BJ, Shutler JD, Widdicombe S, Broderick AC. Global review and inventory: how stable isotopes are helping us understand ecology and inform conservation of marine turtles. Mar Ecol Prog Ser. 2019; 613:217-45. https://doi.org/10.3354/meps12889.

Hironobu D. On a leathery turtle from the sea near Korea. Journal of Chosen National Historical Society. 1936a;21:109-12 (In Japanese).

Hironobu D. Report on a Chelonia japonica from the sea near Korea. Plant and Animal. 1936b;4:797-8 (In Japanese).

Hong SY, Park KY, Park CW, Han CH, Suh HL, Yun SG, Song CB, Jo SG, Lim HS, Kang YS, Kim DJ, Ma CW, Son MH, Kim KB, Choi SD, Park KY, Oh CW, Kim DN, Shon HS, Kim JN, Choi JH, Kim MH, Choi IY. Marine invertebrates in Korean coasts. Seoul: Academy; 2006.

Howell LN, Reich KJ, Shaver DJ, Landry AM, Gorga CC. Ontogenetic shifts in diet and habitat of juvenile green sea turtles in the northwestern Gulf of Mexico. Mar Ecol Prog Ser. 2016;559:217-29. https://doi.org/10.3354/meps11897.

Hughes GR. The sea turtles of South-east Africa. 2. The biology of the Tongaland loggerhead turtle Caretta caretta L. with comments on the leatherback turtle Dermochelys coriacea L. and the green turtle Chelonia mydas L. in the study region. Oceanographic Research Institute. 1974:96.

IUCN. The IUCN red list of threatened species. Version 2021-1. https://www. iucnredlist.org (2021). Accessed 24 Aug 2021.

Jang S, Balazs GH, Parker DM, Kim BY, Kim MY, Ng CKY, et al. Movements of green turtles (Chelonia mydas) rescued from pound nets near Jeju Island. Republic of Korea. Chelonian Conserv Biol. 2018;17(2):236-44. https://doi. org/10.2744/CCB-1279.1.

Jarman SN, Deagle BE, Gales NJ. Group-specific polymerase chain reaction for DNA-based analysis of species diversity and identity in dietary samples. Mo Ecol. 2004;13(5):1313-22. https://doi.org/10.1111/j.1365-294X.2004.02109.X.

Jones TT, Seminoff JA. Feeding biology: advances from field-based observations, physiological studies, and molecular techniques. The biology of sea turtles. CRC press. 2013;3:211-47.

Joo S, Han D, Lee EJ, Park S. Use of length heterogeneity polymerase chain reaction (LH-PCR) as noninvasive approach for dietary analysis of Svalbard reindeer, Rangifer tarandus platyrhynchus. PloS One. 2014;9(3):e91552. https:// doi.org/10.1371/journal.pone.0091552.

Jung MM, Moon DY, Kim SH, Kim HS, Kim JW. Observation and record of sea turtles in bycatch and stranding from Jeju Island of Korea. Jour Fish Mar Sci Edu. 2012a;24(5):662-9 (in Korean).

Jung MM, Moon DY, Kim SH, Kim HS, Kim JW. Environmental conditions as accidental nesting place of seaturtle located in Jeju Island of Korea. Jour. Fish Mar Sci Edu. 2012b;24(4):507-15 (in Korean). https://doi.org/10.13000/JFMSE.2 012.24.4.507.

Kelle L, Gratiot N, de Thoisy B. Olive ridley turtle Lepidochelys olivacea in French Guiana: back from the brink of regional extirpation? Oryx. 2009;43(2):243-6. https://doi.org/10.1017/S0030605309001793.

Kim HS, Boo SM, Lee IK, Sohn CH. National list of species of Korea: marine algae. National Institute of Biological Resources; 2013.

Kim IH, Moon DY, Cho IY, Kim MS, An YR, Han D, et al. Occurrence of sea turtles in the Korean waters and the morphological characteristics of two major 
species. Korean J Fish Aquat Sci. 2017;50(3):311-8. https://doi.org/10.5657/ KFAS.2017.0311 (in Korean).

Kim IH, Yi CH, Lee JH, Park D, Cho IY, Han DJ, et al. First record of the olive ridley sea turtle Lepidochelys olivacea (Reptilia: Testudines: Cheloniidae) from South Korea. Curr Herpetol. 2019;38(2):153-9. https://doi.org/10.5358/hsj.38.153.

Kim J, Joo S, Park S. Diet composition of Korean water deer (Hydropotes inermis argyropus) from the Han River Estuary Wetland in Korea using fecal DNA. Mammalia. 2021;85(6):487-93. https://doi.org/10.1515/mammalia-2021-0010.

Klemens MW. Turtle conservation. Washington DC: Smithsonian; 2000.

Koo KS, Han SH, Oh HS. First report of a hybridization between Caretta caretta and Chelonia mydas from Jeju Island. South Korea. Korean J Environ Biol. 2014;32(4):377-81 (in Korean). https://doi.org/10.11626/KJEB.2014.32.4.377.

Kurata Y, Yoneyama S, Tsutsumi S, Kimura J, Hosokawa S. Experiments to increase number of green turtles through the release of the young. Rep Fundam Res Fish Dev Ogasawara Islands. 1978;3:58-80.

Laist DW. Impacts of marine debris: entanglement of marine life in marine debris including a comprehensive list of species with entanglement and ingestion records. In: Marine Debris. Springer; 1997. p. 99-139. https://doi.org/10.1007/ 978-1-4613-8486-1_10.

Laloë J-O, Cozens J, Renom B, Taxonera A, Hays GC. Conservation importance of previously undescribed abundance trends: increase in loggerhead turtle numbers nesting on an Atlantic island. Oryx. 2020;54(3):315-22. https://doi. org/10.1017/S0030605318001497.

Lee D, Son SH, Kim W, Park JM, Joo H, Lee SH. Spatio-temporal variability of the habitat suitability index for chub mackerel (Scomber Japonicus) in the East/ Japan Sea and the South Sea of South Korea. Remote Sens. 2018;10(6):938. https://doi.org/10.3390/rs10060938.

Lee HJ, Kim IH, Kim JK, Jeong S, Park D. First detailed morphological description of the loggerhead sea turtle (Caretta caretta) caught from the Yellow Sea of Korea. J Ecol Environ. 2014;37(4):201-8. https://doi. org/10.5141/ecoenv.2014.024.

Lee Sl, Hwang SJ, Yang JH, Shim JM. Seasonal variation in species composition of gill net and trammel net catches in the coastal waters off Wangdol-cho. Korea. Korean J Ichthyol. 2008;20(4):291-302.

Lee Y, Kang SY. A catalogue of the seaweeds in Korea. Cheju: Cheju National University; 2001.

Lutz PL, Musick JA, Wyneken J. The biology of sea turtles, Volume II. Boca Raton: CRC press; 2002. https://doi.org/10.1201/9781420040807.

Mansfield KL, Putman NF. Oceanic habits and habitats. Biol sea turtles. 2013;3: 189-211.

Márquez RM. Sea turtles of the world. FAO Fish Synopsis. 1990;125(11):1-81.

Mascarenhas R, Santos R, Zeppelini D. Plastic debris ingestion by sea turtle in Paraíba. Brazil. Mar Pollut Bull. 2004;49(4):354-5. https://doi.org/10.1016/j.ma rpolbul.2004.05.006.

Mattlin RH, Cawthorn MW. Marine debris-an international problem. New Zeal Environ. 1986;51:3-6.

Miya M, Sato Y, Fukunaga T, Sado T, Poulsen JY, Sato K, et al. MiFish, a set of universal PCR primers for metabarcoding environmental DNA from fishes: detection of more than 230 subtropical marine species. R Soc Open Sci. 2015;2(7):150088. https://doi.org/10.1098/rsos.150088.

MOF (Ministry of Oceans and Fisheries). 2021. Conservation and Management of Marine Ecosystems Act.

Moon DY, An YR, Jung MM, Kim SY, Choi SK, Lee HY, et al. Satellite tracking of green sea turtles Chelonia mydas in Korean waters. Kor J Fish Aquat Sci. 2011; 44(6):709-16 (in Korean). https://doi.org/10.5657/KFAS.2011.0709.

Moon DY, Jung MM, An YR, Choi SG, Oh BS, Kim ZG, et al. Distribution and strandings of endangered sea turtles in Korean waters. Korean J Fish Aquat Sci. 2009;42(6):657-63 (in Korean). https://doi.org/10.5657/kfas.2009.42.6.657.

Mortimer JA. The feeding ecology of the West Caribbean green turtle (Chelonia mydas) in Nicaragua. Biotropica. 1981;13(1):49-58. https://doi.org/10.2307/23 87870.

Mortimer JA, Esteban N, Guzman AN, Hays GC. Estimates of marine turtle nesting populations in the south-west Indian Ocean indicate the importance of the Chagos Archipelago. Oryx. 2020;54(3):332-43. https://doi.org/10.1017/5003 0605319001108.

Ng CKY, Ang PO, Russell DJ, Balazs GH, Murphy MB. Marine macrophytes and plastics consumed by green turtles (Chelonia mydas) in Hong Kong, South China Sea region. Chelonian Conserv Biol. 2016;15(2):289-92. https://doi. org/10.2744/CCB-1210.1.

NIBR (National Institute of Biological Resources). National list of species of Korea. 2020. http://kbr.go.kr.
NMFS. Recovery plan for US Pacific populations of the hawksbill turtle (Eretmochelys imbricata). National Marine Fisheries Service. Silver Spring, USA. Published online 1998.

Oh CW. Population biology of the swimming crab Portunus trituberculatus (Miers, 1876) (Decapoda, Brachyura) on the western coast of Korea. Yellow Sea. Crustaceana. 2011;84(10):1251-67. https://doi.org/10.1163/001121611X586675.

Park JI, Lee KS. Site-specific success of three transplanting methods and the effect of planting time on the establishment of Zostera marina transplants. Mar Pollut Bull. 2007;54(8):1238-48. https://doi.org/10.1016/j.marpolbul.2007. 03.020.

Piovano S, Lemons GE, Ciriyawa A, Batibasaga A, Seminoff JA. Diet and recruitment of green turtles in Fiji, South Pacific, inferred from in-water capture and stable isotope analysis. Mar Ecol Prog Ser. 2020;640:201-13. https://doi.org/10.3354/meps13287.

Pires MM, Widmer CE, Silva C, Setz EZ. Differential detectability of rodents and birds in scats of ocelots, Leopardus pardalis (Mammalia: Felidae). Zool. 2011; 28(2):280-3. https://doi.org/10.1590/S1984-46702011000200019.

Plotkin PT, Wicksten MK, Amos AF. Feeding ecology of the loggerhead sea turtle Caretta caretta in the Northwestern Gulf of Mexico. Mar Biol. 1993;115(1):1-5. https://doi.org/10.1007/BF00349379.

Prior B, Booth DT, Limpus CJ. Investigating diet and diet switching in green turtles (Chelonia mydas). Aust J Zool. 2015;63(6):365-75. https://doi.org/10.1 071/ZO15063.

Rasmussen AR, Murphy JC, Ompi M, Gibbons JW, Uetz P. Marine reptiles. PLoS One. 2011;6(11):e27373. https://doi.org/10.1371/journal.pone.0027373.

Reynolds JC, Aebischer NJ. Comparison and quantification of carnivore diet by faecal analysis: a critique, with recommendations, based on a study of the fox Vulpes vulpes. Mammal rev. 1991;21(3):97-122. https://doi.org/10.1111/j.13 65-2907.1991.tb00113.x.

Richardson Jl, McGillivary P. Post-hatchling loggerhead turtles eat insects in Sargassum community. Mar Turt Newsl. 1991;55:2-5.

Russell DJ, Balazs GH. Dietary shifts by green turtles (Chelonia mydas) in the Kāne'ohe Bay Region of the Hawaiian Islands: a 28-year study. Pacific Sci. 2009;63(2):181-92. https://doi.org/10.2984/049.063.0202.

Russell DJ, Balazs GH. Increased use of non-native algae species in the diet of the green turtle (Chelonia mydas) in a primary pasture ecosystem in Hawaii. Aquat Ecosyst Health Manag. 2015;18(3):342-6. https://doi.org/10.1080/14634 988.2015.1027140.

Santos BS, Kaplan DM, Friedrichs MAM, Barco SG, Mansfield KL, Manning JP. Consequences of drift and carcass decomposition for estimating sea turtle mortality hotspots. Ecol Indic. 2018;84:319-36. https://doi.org/10.1016/j. ecolind.2017.08.064

Schuyler Q, Hardesty BD, Wilcox C, Townsend K. Global analysis of anthropogenic debris ingestion by sea turtles. Conserv Biol. 2014;28(1):129-39. https://doi. org/10.1111/cobi.12126.

Shaver DJ. Feeding ecology of wild and head-started Kemp's ridley sea turtles in south Texas waters. J Herpetol. 1991;25(3):327-34. https://doi.org/10.2307/1 564592.

Stiller JW, McClanahan ANA. Phyto-specific 165 rDNA PCR primers for recovering algal and plant sequences from mixed samples. Mol Ecol Notes. 2005;5(1):13. https://doi.org/10.1111/j.1471-8286.2004.00805.X.

Stringell TB, Clerveaux WV, Godley BJ, Kent FE, Lewis ED, Marsh JE, et al. Taxonomic distinctness in the diet of two sympatric marine turtle species. Mar Ecol. 2016;37(5):1036-49. https://doi.org/10.1111/maec.12349.

Thomson JA, Heithaus MR, Burkholder DA, Vaudo JJ, Wirsing AJ, Dill LM. Site specialists, diet generalists? Isotopic variation, site fidelity, and foraging by loggerhead turtles in Shark Bay. Western Australia. Mar Ecol Prog Ser. 2012; 453:213-26. https://doi.org/10.3354/meps09637.

Tomas J, Aznar FJ, Raga JA. Feeding ecology of the loggerhead turtle Caretta caretta in the western Mediterranean. J Zool. 2001;255(4):525-32. https://doi. org/10.1017/s0952836901001613.

Valentini A, Miquel C, Nawaz MA, Bellemain E, Coissac E, Pompanon F, et al. New perspectives in diet analysis based on DNA barcoding and parallel pyrosequencing: the trnL approach. Mol Ecol Resour. 2009;9(1):51-60. https:// doi.org/10.1111/j.1755-0998.2008.02352.x.

Van Nierop MM, Den Hartog JC. A study on the gut contents of live juvenile loggerhead turtles, Caretta caretta (Linnaeus)(Reptilia, Cheloniidae), from the south-eastern part of the North Atlantic Ocean, with emphasis on coelenterate identification. Zool Meded. 1984;59(4):35-54.

Vélez-Rubio GM, Cardona L, López-Mendilaharsu M, Souza GM, Carranza A González-Paredes D, et al. Ontogenetic dietary changes of green turtles 
(Chelonia mydas) in the temperate southwestern Atlantic. Mar Biol. 2016; 163(3):57. https://doi.org/10.1007/s00227-016-2827-9.

Vrijenhoek R. DNA primers for amplification of mitochondrial cytochrome c oxidase subunit I from diverse metazoan invertebrates. Mol Mar Biol Biotechnol. 1994;3(5):294-9.

Wallace BP, DiMatteo AD, Hurley BJ, Finkbeiner EM, Bolten AB, Chaloupka MY, et al. Regional management units for marine turtles: a novel framework for prioritizing conservation and research across multiple scales. PLoS One. 2010; 5(12):e15465. https://doi.org/10.1371/journal.pone.0015465.

Wilcox C, Puckridge M, Schuyler QA, Townsend K, Hardesty BD. A quantitative analysis linking sea turtle mortality and plastic debris ingestion. Sci Rep. 2018; 8(1):1-11. https://doi.org/10.1038/s41598-018-30038-z.

Williard AS, Wyneken J, Lohmann KJ, Musick JA. Physiology as integrated systems. In: The Biology of Sea Turtles, Volume III. Boca Raton: CRC press; 2013. p.1-30, DOl: https://doi.org/10.1201/b13895-2.

Wolfe DA. Persistent plastics and debris in the ocean: an international problem of ocean disposal. Mar Pollut Bull. 1987;18(6):303-5. https://doi.org/10.1016/S002 5-326X(87)80015-2.

Won HG. Amphibian and reptiles of Chosun. Pyeongyang Printing Office: North Korea, Pyeongyang; 1971. (in Korean)

Won JH, Lee YW. Spatiotemporal variations of marine environmental parameters in the South-western region of the East Sea. Sea. 2015;20(1):16-28. https:// doi.org/10.7850/jkso.2015.20.1.16

Zhao D, Yang C, Ma J, Zhang X, Ran J. Vertebrate prey composition analysis of the Pallas's cat (Otocolobus manu) in the Gongga Mountain Nature Reserve, based on fecal DNA. Mammalia. 2020;84(5):449-57. https://doi.org/10.1515/ mammalia-2018-0144.

Zhao H, Feng Y, Dong C, Li Z. Spatiotemporal distribution of Decapterus maruadsi in spring and autumn in response to environmental variation in the northern South China Sea. Reg Stud Mar Sci. 2021;45:101811. https://doi.org/10.1016/j. rsma.2021.101811.

\section{Publisher's Note}

Springer Nature remains neutral with regard to jurisdictional claims in published maps and institutional affiliations.

Ready to submit your research? Choose BMC and benefit from:

- fast, convenient online submission

- thorough peer review by experienced researchers in your field

- rapid publication on acceptance

- support for research data, including large and complex data types

- gold Open Access which fosters wider collaboration and increased citations

- maximum visibility for your research: over $100 \mathrm{M}$ website views per year

At $\mathrm{BMC}$, research is always in progress.

Learn more biomedcentral.com/submissions 